\title{
Pengaruh Pemberian Kuis di Awal Pembelajaran pada Model Discovery Learning terhadap Hasil Belajar Peserta Didik Kelas XI MIA SMA Negeri 1 Gowa (Studi pada Materi Pokok Larutan Penyangga)
}

The Effect of Giving Quizzes at the Beginning of Discovery Learning to the Learning Outcomes of Class XI MIA at State Senior High School 1 Gowa (on the Subject of Buffer Solution)

\author{
${ }^{1)}$ Nurfahraini, ${ }^{2)}$ Alimin, ${ }^{3)}$ Muharram \\ Universitas Negeri Makassar, Jalan Daeng Tata Makassar, Kampus UNM Parangtambung 90224 \\ Email: lindahaslinda0607@gmail.com
}

\begin{abstract}
ABSTRAK
Penelitian ini adalah penelitian eksperimen semu yang bertujuan untuk mengetahui pengaruh pemberian kuis di awal pembelajaran dalam model dicovery learning terhadap hasil belajar peserta didik kelas XI MIA SMA Negeri 1 Gowa pada materi pokok larutan penyangga. Desain penelitian yang digunakan adalah posttest only control group design. Variabel bebas dalam penelitian ini adalah pemberian kuis di awal pembelajaran pada model discovery learning dan model discovery learning tanpa pemberian kuis di awal pembelajaran, sedangkan variabel terikatnya adalah hasil belajar peserta didik. Populasi dalam penelitian ini adalah seluruh peserta didik kelas XI MIA SMA Negeri 1 Gowa yang terdiri dari delapan kelas. Sampel penelitian ini adalah kelas XI MIA sebagai kelas eksperimen dan kelas XI MIA 4 sebagai kelompok kontrol yang ditentukan dengan metode simple random sampling. Data hasil penelitian diperoleh melalui hasil posttest berupa soal objektif materi larutan penyangga. Data hasil posttest dianalisis dengan menggunakan statistik deskriptif dan statistik inferensial. Hasil pengujian hipotesis menggunakan uji-t dengan $\alpha=0,05$ menunjukkan $t_{\text {hitung }}>t_{\text {tabel }}(4,49>$ 1,67) dapat disimpulkan bahwa $\mathrm{H}_{0}$ ditolak dan $\mathrm{H}_{1}$ diterima berarti ada pengaruh pemberian kuis di awal pembelajaran dalam model discovery learning terhadap hasil belajar peserta didik kelas XI MIA SMA Negeri 1 Gowa pada materi pokok larutan penyangga.
\end{abstract}

Kata kunci: Kuis di Awal, discovery learning, dan hasil belajar

\section{ABSTRACT}

This reserch was a quasi-experiment aiming at examining the effect of giving quizzes at the beginning of dicovery learning model-based learning on the learning outcomes of the eleventh grade students of 
Pengaruh Pemberian Kuis di Awal Pembelajaran pada Model Discovery Learning terhadap Hasil Belajar Peserta Didik Kelas XI MIA SMA Negeri I Gowa (Studi pada Materi Pokok Larutan Penyangga)

Mathematics and Natural Science Class at State Senior High School 1 Gowa on the subject of buffer solution. The research design employed was the post test only control group design. The independent variables in this study were the giving of quizzes at the beginning of learning in the discovery learning model and the discovery learning model without the quiz giving at the beginning of learning, while the dependent variable was the learning outcomes of students. The population in this study were all of the eleventh grade students of Mathematics and Natural Science Class at State Senior High School 1 Gowa encompassing eight classes. The samples taken in this study were class XI MIA 2 as the experimental group and class XI MIA 4 as the control group determined by the simple random sampling method. The research data were collected from the posttest results in the form of objective questions about buffer solution material. The post-test data were analyzed by employing descriptive and inferential statistics. The hypothesis testing results utilizing t-test with $\alpha=0.05$ revealed that $t_{\text {count }}>t_{\text {table }}(4,49>1,67)$ which can be concluded that $\mathrm{H}_{0}$ was rejected and $\mathrm{H}_{1}$ was accepted meaning there was an influence of giving quizzes at the beginning of discovery learning model-based teaching on the learning outcomes of the eleventh grade students of Mathematics and Natural Science Class at State Senior High School 1 Gowa on the subject of buffer solution.

Keywords: Quiz at the beginning, discovery learning, learning outcome

\section{PENDAHULUAN}

Peraturan menteri pendidikan dan kebudayaan nomor 65 tahun 2013 tentang standar proses, model pembelajaran yang diutamakan dalam implementasi kurikulum 2013 adalah model pembelajaran inkuiri (inquiry based learning), model pembelajaran discovery (discovery learning), model pembelajaran berbasis projek (project based learning), dan model pembelajaran berbasis permasalahan (problem based learning). Keempat model tersebut memungkinkan peserta didik berperan aktif dalam menemukan, mengkonsep, dan memahami konsep yang dipelajari. Salah satu model yang memungkinkan peserta didik berperan aktif dalam proses pembelajaran adalah model discovery learning.
Model discovery learning berorientasi pada keterlibatan peserta didik untuk mencari dan menemukan pengetahuan melalui kegiatan percobaan, observasi, atau pencarian bukti lainnya, dengan kata lain model discovery learning merupakan pembentukan kategori atau konsep, yang memungkinkan terjadinya generalisasi yang dilakukan atas kemampuan yang dimiliki peserta didik sendiri (Darmawan, 2018). Bagi peserta didik, pembelajaran dengan menggunakan model ini akan lebih bermakna dan hasilnya akan bertahan lama karena peserta didik berpartisipasi secara aktif dalam mendapatkan pengetahuan dan pengalaman sendiri sehingga peserta didik dapat mecapai tujuan pembelajaran yang telah disusun. 
Model discovery learning menuntut peserta didik untuk belajar secara mandiri. Peserta didik belajar melalui keterlibatan aktif dengan konsep dan prinsip dalam memecahkan masalah, dan guru mendorong peserta didik utuk mendapatkan pengalaman dengan melakukan kegiatan yang memungkinkan peserta didik menemukan prinsip untuk dirinya sendiri, bukan memberi tahu tetapi memberikan kesempatan atau dengan berdialog agar peserta didik menemukan sendiri suatu konsep (Supriyanto, 2014).

Model discovery learning dianggap cocok diterapkan dalam pembelajaran kimia karena kebanyakan konsep yang dipelajari dalam kimia merupakan sesuatu yang bersifat mikro dan terdapat beberapa konsep perhitungan salah satunya yakni pada materi larutan penyangga, yang tidak hanya mengandalkan kemampuan menghafal saja, melainkan juga menuntut kemampuan peserta didik dalam memahami dan menganalisis materi pembelajaran.

Berdasarkan hasil observasi yang telah dilakukan di SMA Negeri 1 Gowa menunjukkan bahwa pembelajaran yang telah dilakukan dengan menggunakan model discovery learning belum sepenuhnya berjalan maksimal, yang dapat dilihat dari masih banyaknya hasil belajar peserta didik yang belum mencapai KKM pelajaran kimia yang telah ditetapkan oleh SMA Negeri 1 Gowa yaitu 75. Hal ini disebabkan oleh beberapa faktor, diantaranya adalah kurangnya minat belajar peserta didik serta konsep dan teori yang kadang susah dijangkau oleh pemikiran peserta didik. Untuk meminimalisir masalah pada penerapan model discovery learning yang telah dilakukan, maka guru dapat memberikan perlakuan yang berbeda saat proses pembelajaran, salah satunya yakni dengan pemberian kuis di awal pembelajaran.

Pemberian kuis di awal pembelajaran merupakan pemberian tes singkat di awal pembelajaran dengan menggunakan soal yang sederhana sesuai dengan tujuan pembelajaran. Pemberian kuis ini akan memberikan dampak kepada peserta didik seperti membuat peserta didik lebih teratur dalam belajar, lebih rajin serta dapat memfokuskan dan mempersiapkan peserta didik dalam mengikuti proses pembelajaran. Pada saat proses pembelajaran peserta didik akan aktif dalam bertanya mengenai materi yang dibahas. Peserta didik akan mengetahui diadakannya kuis untuk pertemuan selanjutnya dan karena itu pemberian kuis di awal pembelajaran dapat meningkatkan hasil belajar peserta didik (Side, 2017).

Pemberian kuis di awal pembelajaran pada model discovery learning dapat menjadikan peserta didik lebih termotivasi untuk terlibat secara aktif dalam proses pembelajaran. Pada umumnya, peserta didik cenderung belajar dengan hafalan daripada secara aktif mencari untuk membangun pemahaman mereka sendiri terhadap konsep kimia. Pada materi larutan penyangga mengutamakan pemahaman dan kurangnya minat belajar peserta didik 
Pengaruh Pemberian Kuis di Awal Pembelajaran pada Model Discovery Learning terhadap Hasil Belajar Peserta Didik Kelas XI MIA SMA Negeri I Gowa (Studi pada Materi Pokok Larutan Penyangga)

sangat mempengaruhi hasil belajar peserta didik. Pemberian kuis di awal pembelajaran dapat semangat belajar peserta didik untuk terlibat secara aktif dalam proses pembelajaran sehingga dapat mencapai hasil belajar peserta didik yang diharapkan. Pemberian kuis di awal pembelajaran dapat meningkatkan hasil belajar peserta didik. Hal ini didukung oleh Sutardi (2013), peningkatan hasil belajar terjadi karena pemberian kuis di awal pembelajaran dapat menjadikan peserta didik lebih antusias sehingga mendorong peserta didik mengikuti setiap kegiatan pembelajaran.

Berdasarkan latar belakang di atas, maka akan dilakukan penelitian tentang pengaruh pemberian kuis di awal pembelajaran pada model discovery learning terhadap hasil belajar peserta didik.

\section{METODE PENELITIAN}

Penelitian ini merupakan penelitian eksperimen semu. Variabel bebas dari penelitian ini adalah pemberian kuis di awal pertemuan dan model discovery learning sedangkan variabel terikatnya yaitu hasil belajar peserta didik.

Instrumen yang digunakan dalam penelitian ini adalah instrumen tes hasil belajar yang telah diuji validitasnya dengan menggunakan validitas item dan validitas isi. Selain itu menggunakan lembar observasi keterlaksanaan proses pembelajaran.

Hasil belajar peserta didik yang diperoleh dalam bentuk skor dikonversi ke bentuk nilai dengan rumus:

Nilai $=$ (skor yang diperoleh peserta didik)/(skor maksimun) x 100

Tabel 1. Kriteria Ketuntasan Belajar Peserta Didik SMA Negeri 1 Gowa

\begin{tabular}{|c|c|}
\hline Nilai & Kategori \\
\hline$\geq 75$ & Tuntas \\
$<75$ & Tidak Tuntas \\
\hline
\end{tabular}

(Sumber: SMA Negeri 1 Gowa)

Adapun hipotesis dari penelitian ini yaitu "ada pengaruh pemberian kuis di awal pembelajaran pada model discovery learning terhadap hasil belajar peserta didik kelas XI MIA SMA Negeri 1 Gowa pada materi pokok larutan penyangga"

\section{HASIL DAN PEMBAHASAN}

\section{A. Hasil Penelitian}

\section{Analisis Statistik Deskriptif}

Analisis statistik deskriptif bertujuan untuk memberikan gambaran umum mengenai karakteristik pencapaian hasil belajar peserta didik pada kelas eksperimen dan kelas kontrol. Tabel 2 menunjukkan bahwa nilai rata-rata yang diperoleh kelompok eksperimen lebih tinggi dibandingkan kelompok kontrol. 
Tabel 2. Nilai Statistik Hasil Belajar Peserta Didik

\begin{tabular}{|l|c|l|l|}
\hline \multirow{2}{*}{ No } & \multirow{2}{*}{ Statistik } & \multicolumn{2}{|c|}{ Nilai Statistik } \\
\cline { 3 - 4 } & & $\begin{array}{l}\text { Kelompok } \\
\text { Eksperimen }\end{array}$ & Kelompok Kontrol \\
\cline { 3 - 4 } & & Posttest & Posttest \\
\hline 1 & Jumlah Peserta Didik & 30 & 30 \\
\hline 2 & Nilai Tertinggi & 95 & 95 \\
\hline 3 & Nilai Terendah & 65 & 50 \\
\hline 4 & Nilai Rata-rata & 80,06 & 77,23 \\
\hline 5 & Median & 79,93 & 77,93 \\
\hline 6 & Modus & 82,5 & 78,3 \\
\hline 7 & Standar Deviasi & 8,85 & 11,93 \\
\hline
\end{tabular}

\section{Analisis Statistik Inferensial}

Uji normalitas dilakukan dengan tujuan untuk mengetahui normal atau tidaknya populasi yang digunakan. Uji normalitas menggunakan statistik uji chi-kuadrat $\left(\chi^{2}\right)$, data dikatakan normal apabila $\chi^{2}{ }^{2}$ hitung $<\chi^{2}$ tabel. Dari hasil perhitungan analisis statistik inferensial untuk data hasil belajar peserta didik pada kelompok eksperimen diperoleh $\chi_{\text {hitung }}^{2}=1,97$ dan kelompok kontrol diperoleh $\chi^{2}$ hitung $=6,67$. Nilai untuk $\chi^{2}$ tabel pada taraf kepercayaan $(\alpha)=0,05$ dan derajat kebebasan $(\mathrm{dk})=3$ diperoleh nilai $\chi_{\text {tabel }}^{2}=7,8150$. Pada kelompok eksperimen $\quad \chi^{2}$ hitung $<\chi^{2}$ tabel $\quad$ dan kelompok kontrol $\chi^{2}$ hitung $<\chi^{2}$ tabel maka disimpulkan bahwa hasil belajar pada kelompok eksperimen dan kelompok kontrol berdistribusi normal.

Uji homogenitas dilakukan untuk mengetahui apakah data dari kedua kelas bersifat homogen atau tidak.
Kriteria pengujian homogenitas yaitu Fhitung $<$ Ftabel. Berdasarkan hasil uji homogenitas untuk data hasil belajar dengan menggunakan varians dari kelompok kontrol sebagai varians terbesar dan varians dari kelompok eksperimen sebagai varians terkecil, maka diperoleh data $F_{\text {hitung }}=1,82$. Nilai $F_{\text {tabel, }}$, pada taraf kepercayaan 0,05 sebesar 1,86 karena nilai $\mathrm{F}_{\text {hitung }}<\mathrm{F}_{\text {tabel }}$ maka dapat disimpulkan bahwa varians kelompok eksperimen dan kelompok kontrol berasal dari populasi yang homogen.

Hasil uji prasyarat untuk hasil belajar, data berdistribusi normal dan berasal dari varians yang homogen, maka dilanjutkan dengan uji hipotesis. Pada uji hipotesis digunakan uji $t$ satu pihak. Uji $t$ dilakukan pada masingmasing kelompok eksperimen dan kelompok kontrol.

Hasil perhitungan, diperoleh nilai thitung $=4,49$ dan nilai tabel pada 
Pengaruh Pemberian Kuis di Awal Pembelajaran pada Model Discovery Learning terhadap Hasil Belajar Peserta Didik Kelas XI MIA SMA Negeri I Gowa (Studi pada Materi Pokok Larutan Penyangga)

taraf kepercayaan $(\alpha)=0,05$ dan derajat kebebasan $(\mathrm{dk})=58$ yaitu 1,67 . Dari analisis uji hipotesis ini diperoleh $\mathrm{t}_{\text {hitung }}>t_{\text {tabel }}$, maka $\mathrm{H}_{0}$ ditolak dan $\mathrm{H}_{1}$ diterima. Dengan demikian, dapat disimpulkan bahwa terdapat pengaruh pemberian kuis di awal pembelajaran pada model discovery learning terhadap hasil belajar peserta didik kelas XI MIA SMA Negeri 1 Gowa pada materi pokok larutan penyangga.

\section{B. Pembahasan}

Penelitian ini dilakukan untuk mengetahui adanya pengaruh pemberian kuis di awal pembelajaran pada model discovery learning terhadap hasil belajar peserta didik di SMA Negeri 1 Gowa pada materi pokok larutan penyangga. Penelitian ini menggunakan dua kelompok yang terdiri dari kelompok eksperimen (XI $\mathrm{MIA}_{2}$ ) dan kelompok kontrol (XI MIA4). Kedua kelompok yang dijadikan sampel penelitian diberikan perlakuan dengan menggunakan model discovery learning, perbedaannya terletak pada perlakuan yang diberikan yaitu kelompok eksperimen diberikan kuis di awal pembelajaran sedangkan kelompok kontrol tidak diberikan kuis di awal pembelajaran.

Berdasarkan hasil perhitungan analisis deskriptif untuk kedua kelompok menghasilkan data hasil belajar yang berbeda. Hasil posttes kelompok eksperimen diperoleh nilai terendah 65 dan nilai tertinggi 95, sedangkan untuk kelompok kontrol diperoleh nilai terendah 50 dan nilai tertinggi yakni 95. Berdasarkan data hasil belajar yang berbeda bahwa kelompok eksperimen lebih unggul dengan nilai rata-rata 80,06 sedangkan kelompok kontrol 77,23. Menunjukkan bahwa pada kelompok eksperimen memiliki hasil belajar yang lebih tinggi dibandingkan kelompok kontrol.

Hasil analisis deskriptif juga menyajikan persentase ketuntasan kelas dan ketuntasan indikator. Berdasarkan kategori tuntas dan tidak tuntas maka persentase ketuntasan kelompok eksperimen adalah 83,33\% sedangkan kelompok kontrol adalah $66,67 \%$. Hal ini menunjukkan bahwa pencapaian hasil belajar peserta didik yang diajar dengan kuis di awal pembelajaran pada model Discovery Learning lebih tinggi daripada peserta didik yang diajar tanpa kuis di awal pembelajaran pada model Discovery Learning. Persentase peserta didik yang memperoleh ketuntasan dari kelompok yang diberi kuis di awal pembelajaran mencapai standar ketuntasan kelas sedangkan kelas yang tanpa kuis di awal pembelajaran tidak mencapai standar ketuntasan kelas yaitu $80 \%$.

Berdasarkan frekuensi ketuntasan tiap indikator untuk kedua kelompok tersebut, kelompok eksperimen lebih unggul karena melulusi lima indikator sedangkan kelompok kontrol hanya melulusi tiga indikator. Secara umum pada beberapa indikator yang tuntas dari kelompok eksperimen dan kelompok kontrol, kelompok eksperimen memperoleh nilai persentase ketuntasan yang lebih tinggi daripada kelompok kontrol tetapi pada indikator satu terkait dengan definisi larutan penyangga kelompok kontrol meperoleh nilai persentase ketuntasan yang lebih tinggi 
daripada kelompok eksperimen, hal ini dikarenakan pada indikator satu pada pertemuan pertama peseta didik pada kelompok eksperimen baru menyesuaikan diri dengan pemberian kuis di awal pembelajaran. Dari uraian di atas maka dapat disimpulkan bahwa rata-rata ketuntasan indikator kelompok eksperimen lebih tinggi sebesar $85,42 \%$ sedangkan kelompok kontrol $65 \%$. Hal ini menunjukkan bahwa pencapaian hasil belajar peserta didik yang diajar dengan kuis di awal pembelajaran pada model discovery learning lebih tinggi daripada peserta didik yang diajar tanpa kuis di awal pembelajaran pada model discovery learning. Hal ini dikarenakan peserta didik yang diberikan kuis terlihat lebih antusias untuk belajar karena peserta didik sudah memiliki pengetahuan awal sebelum memasuki proses pembelajaran.

Untuk memperkuat hasil analisis deskriptif, maka dilakukan analisis lebih lanjut yaitu analisis statistik inferensial yang bertujuan untuk membuktikan kebenaran dari hipotesis yang diajukan. Sebelum melakukan uji hipotesis, terlebih dahulu dilakukan uji prasyarat yakni uji normalitas dan homogenitas data. Berdasarkan hasil uji normalitas, diketahui bahwa kelompok eksperimen dan kelompok kontrol berasal dari kelompok yang terdistribusi normal. Sedangkan uji homogenitas menunjukkan bahwa data berasal dari varians yang homogen. Oleh karena data yang terdistribusi normal dan homogen, maka pengujian hipotesis dapat dilakukan dengan menggunakan uji hipotesis statistik parametrik (uji t).
Hasil uji t menunjukkan bahwa pemberian kuis di awal pembelajaran pada model discovery learning memberikan pengaruh terhadap hasil belajar peserta didik. Hal ini ditunjukkan dengan perolehan nilai $\mathrm{t}_{\text {hitung }}$ yang lebih besar daripada $\mathrm{t}_{\text {tabel }}$ yang artinya $\mathrm{H}_{0}$ ditolak dan $\mathrm{H}_{1}$ diterima.

Peserta didik yang mengetahui akan diberikan ulangan atau kuis akan lebih mempersiapkan dirinya di rumah sehingga adanya perbedaan hasil belajar kelompok eksperimen dengan kelompok kontrol pada materi pokok larutan penyangga disebabkan oleh pengetahuan awal yang dimiliki peserta didik pada saat peserta didik mempersiapkan kuis di awal pembelajaran. Di kelompok eksperimen yang diajar dengan pemberian kuis di awal pembelajaran peserta didik terlihat lebih antusias untuk belajar karena peserta didik sudah memiliki pengetahuan awal sebelum memasuki proses pembelajaran. Berbeda dengan kelompok kontrol, dimana belajarkan tanpa menggunakan kuis di awal pembelajaran, peserta didik hanya belajar dan memperoleh pengetahuannya selama proses pembelajaran yang terjadi didalam kelas saja.

Banyak penelitian yang telah menyimpulkan bahwa pemberian kuis di awal pembelajaran dapat meningkatkan hasil belajar. Seperti pada penelitian sebelumnya yang dilakukan oleh Sutardi (2013), pemberian kuis di awal pertemuan secara kontinu yang didukung oleh suasana belajar yang menyenangkan 
Pengaruh Pemberian Kuis di Awal Pembelajaran pada Model Discovery Learning terhadap Hasil Belajar Peserta Didik Kelas XI MIA SMA Negeri I Gowa (Studi pada Materi Pokok Larutan Penyangga)

diharapkan akan membuat peserta didik lebih siap dan termotivasi untuk belajar serta aktif mengikuti pelajaran yang pada akhirnya dapat meningkatkan hasil belajarnya. Asri (2010) mengemukakan bahwa dengan memberikan kuis secara kontinu, setiap proses belajar mengajar di sekolah akan memberikan dampak positif dalam pencapaian hasil belajar peserta didik sehingga sangat berperan dalam meningkatkan hasil belajar kimia itu sendiri.

Secara keseluruhan persentase rata-rata keterlaksanaan pembelajaran dengan menggunakan pemberian kuis di awal pembelajaran dan keterlaksanaan pembelajaran tanpa menggunakan pemberian kuis di awal pembelajaran pada model discovery learning yaitu 92,71\% dan 93,51\% (Lampiran C halaman 234-242). Hal ini menunjukkan bahwa proses pembelajaran terlaksana dengan baik.

\section{KESIMPULAN DAN SARAN}

\section{A. Kesimpulan}

dan perdasarkan hasil penelitian disimpulkan bahwa terdapat pengaruh pemberian kuis di awal pembelajaran pada model discovery learning terhadap hasil belajar peserta didik kelas XI MIPA SMA Negeri 1 Gowa pada materi pokok larutan penyangga.

\section{B. Saran}

Berdasarkan hasil yang diperoleh dari penelitian ini, maka dikemukakan saran-saran sebagai berikut:
1. Bagi guru, sebaiknya mempertimbangkan penggunaan pemberian kuis diawal pembelajaran pada model discovery learning agar peserta didik lebih aktif guna meningkatkan hasil belajar peserta didik.

2. Bagi peneliti selanjutnya, penelitian ini dapat menjadi referensi atau inspirasi bagi peneliti selanjutnya dalam proses pembuatan judul dan penulisan skripsi.

\section{DAFTAR PUSTAKA}

Asri, Zainal.2010. Micro Teaching. Jakarta: Raja Gravindo Persada.

Chang, Raymond. 2005. Kimia Dasar Konsep-konsep Inti Edisi Ketiga Jilid 1. Jakarta: Erlangga.

Dahar, Ratna Wilis. 2006. Teori-teori Belajar dan Pembelajaran. Bandung: Erlangga.

Danial, Muhammad. Jestiana Rahel, dan Iwan Dini. 2013. Perbandingan Hasil Belajar Siswa yang Diberi Tugas Rumah dan Kuis pada Model Pembelajaran Langsung (Studi pada Materi Pokok Reaksi Redoks). Jurnal Chemica. Vol. 14. No. 1.

Darmawan, Deni dan Dinn Wahyudin. 2018. Model Pembelajaran Di Sekolah. Bandung: PT Raja Rosdakarya.

Depdiknas. 2002. Kamus Besar Bahasa Indonesia Edisi Kedua. Jakarta: Balai Pustaka. 
Hamalik, Oemar. 2006. Proses Belajar Mengajar. Bandung: Bumi Aksara.

Kemendikbud. 2014. Model Pembelajaran Penemuan (Discovery Learning). Jakarta : Kemendikbud.

Permendikbud. 2013. Jurnal Lampiran Peraturan Menteri Pendidikan dan Kebudayaan Republik Indonesia Nomor 65 Tahun 2013 Tentang Standar Proses Pendidikan Dasar dan Menengah.

Salempa, Pince. Muhammad Anwar dan Sitti Fatimah Ramadhani. 2013. Pengaruh Pemberian Kuis di Akhir pertemuan pada pembelajaran Inkuiri Terbimbing Terhadap Hasil Belajar Siswa Kelas X SMA Negeri 2 watansoppeng Studi pada Materi pokok Ikatan Kimia. Jurnal Chemica. Vol. 14. No. 2.

Side, Sumiati. Taty Sulastry dan Rafsanjani Supardi. 2017. Pengaruh Pemberian Kuis di Awal Pembelajaran pada Model Pembelajaran Inkuiri Terhadap Hasil Belajar Siswa Kelas X SMK Negeri 2 Parepare ( Studi pada Materi Pokok Ikatan Kimia ). Jurnal Chemica. Vol. 18. No. 1.

Siswanto. 2018. Penilaian Dan Pengukuran Sikap Dan Hasil Belajar Peserta Didik. Bandung: Bossscript.

Sufairoh. 2016. Pendekatan Saintifik dan Model Pembelajaran K-13.
Jurnal Pendidikan Profesional, Vol. 5. No.3.

Supriyanto, Bambang. 2014. Penerapan Discovery Learning Untuk Meningkatkan Hasil Belajar Siswa Kelas Vi B Mata Pelajaran Matematika Pokok Bahasan Keliling Dan Luas Lingkaran Di Sdn Tanggul Wetan 02 Kecamatan Tanggul Kabupaten Jember. Pancaran. Vol. 3. No. 2.

Susetyo, Budi. 2010. Prosedur Penyusunan dan Analisis untuk Penilaian Tes Hasil Belajar Bidang Kognitif. Bandung: PT. Refika Aditama.

Sutardi, dkk. 2013. Peningkatan Minta dan Hasil Belajar Siswa dengan Metode Pemberian Quiz Team "Think Fast Do Best" pada Materi Reaksi Oksidasi-Reduksi di Kelas X MAN Model Singkawang. Jurnal Sains dan Tekhnologi. Vol. IX, No.2.

Sutresna. Didin Sholehun dan Teti Herlina. 2016. Buku Siswa Aktif dan Kreatif Belajar Kimia. Jakarta : Grafindo Media Pratama.

Uno, H, B. 2015. Teori Motivasi dan Pengukurannya. Jakarta: Bumi Aksara.

Yani, Ahmad dan Mamat Ruhimat. 2018. Teori Dan Implementasi Pembelajaran Saintifik Kurikulum 2013. Bandung: PT Refika Aditama. 